Abstracta Iranica Abstracta Iranica

Revue bibliographique pour le domaine irano-aryen

Volume 28 | 2007

Comptes rendus des publications de 2005

\title{
« Ethnic Diversity and Territorial Integrity of Iran: Domestic Harmony and Regional Challenges ». Iranian Studies, 38/1, Mars 2005, pp. 23-44.
}

\section{Gilles Riaux}

\section{(2) OpenEdition}

Journals

Édition électronique

URL : http://journals.openedition.org/abstractairanica/18391

DOI : 10.4000/abstractairanica.18391

ISSN : 1961-960X

Éditeur :

CNRS (UMR 7528 Mondes iraniens et indiens), Éditions de l'IFRI

Édition imprimée

Date de publication : 15 mai 2007

ISSN : 0240-8910

Référence électronique

Gilles Riaux, « «Ethnic Diversity and Territorial Integrity of Iran: Domestic Harmony and Regional Challenges ». Iranian Studies, 38/1, Mars 2005, pp. 23-44. », Abstracta Iranica [En ligne], Volume 28 | 2007, document 212, mis en ligne le 18 septembre 2007, consulté le 25 septembre 2020. URL : http:// journals.openedition.org/abstractairanica/18391 ; DOI : https://doi.org/10.4000/abstractairanica. 18391

Ce document a été généré automatiquement le 25 septembre 2020.

Tous droits réservés 


\title{
« Ethnic Diversity and Territorial Integrity of Iran: Domestic Harmony and Regional Challenges ». Iranian Studies, 38/1, Mars 2005, pp. 23-44.
}

\author{
Gilles Riaux
}

1 L'A. propose une réflexion historique des enjeux posés par la diversité ethnique à l'intégrité territoriale de l'Iran. A partir des Safavides, elle a été garantie d'abord par des relations souples entre le centre et la périphérie, matérialisées par les changements de capitale; après l'établissement définitif de la capitale à Téhéran, au XIX ${ }^{\mathrm{e}}$ s., la définition de frontières stables a permis de concrétiser l'intégrité nationale ; enfin sous les Pahlavis la mobilité sociale offerte à tous les Iraniens a renforcé l'unité nationale. De manière impromptue, l'A. présente ensuite trois révoltes majeures qui, en Azerbaïdjan iranien, ont voulu limiter la puissance de l'Etat central et instituer des pouvoirs locaux au XX ${ }^{e}$ s. (Hુiyābānī en 1920, Pīševarī en 1945-1946 et Šarīatmadārī après la Révolution islamique). Il traite enfin de l'accession à l'indépendance de la République d'Azerbaïdjan et des appels éphémères à la création d'un grand Azerbaïdjan par son second Président, Elçibey. L'A. conclut en soulignant que l'intégrité territoriale de l'Iran n'est pas nécessairement un acquis, et qu'elle dépend de l'introduction de réformes garantissant des droits individuels et collectifs.

2 Aucune problématique claire n'émerge de cet article qui ouvre des pistes de réflexion éparses sans les explorer consciencieusement. Il est par exemple désinvolte d'aborder les relations centre-périphérie sans prendre en compte le formidable développement de Téhéran en tant que centre politique, démographique, culturel et économique au cours du XIX ${ }^{\mathrm{e}}$, puis du XX ${ }^{\mathrm{e}}$ siècle. 
INDEX

Thèmes : 4.3. Histoire de l'Iran moderne (à partir de 1905)

\section{AUTEURS}

GILLES RIAUX

Paris 